\title{
A Study of the Effects of Exchange Rates on the Stock Companies in the Petrochemical Industry of the Eurozone
}

\section{Jana Šimáková}

School of Business Administration in Karviná, Silesian University in Opava, The Czech Republic

simakova@opf.slu.cz
CroEconSur

Vol. 22

No. 1

June 2020

pp. $103-122$

Received: November 5, 2019

Accepted: May 13, 2020

Research Article

doi:10.15179/ces.22.1.4

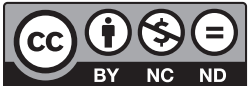

\section{Abstract}

Considering the importance of the petrochemical industry as one of the strategic sectors in the eurozone economy, this study aims to evaluate the relationship between exchange rate fluctuations and stock market prices in the eurozone petrochemical industry. This paper applies Jorion's model and panel regression framework to monthly data spanning from 2002 to 2018. Panel regressions were estimated for three periods: the whole sample, the period before the financial crisis, and the period after the crisis. These divisions allowed for the testing of the persistence of exchange rate exposure in the petrochemical sector over time. This paper provides evidence of the magnitude of the impact of exchange rate shocks. Additionally, this paper shows that the petrochemical sector of the eurozone was exposed to significant exchange rate risk at the 1 percent level during the whole 
sample period and that this exposure was still present even after we split the test period into the precrisis and postcrisis datasets. However, foreign exchange rate exposure increased after the start of the financial crisis in 2008. The negative coefficient of the variable representing exposure suggests that the depreciation of the euro was followed by an increase in the stock returns of the petrochemical companies in the eurozone.

Keywords: exchange rate, petrochemical industry, stock prices, currency exposure JEL classification: F31, G12

\section{Introduction}

As more than 95 percent of products and facilities contain some component produced by the petrochemical industry through a series of ongoing simple or complex oil and gas conversion processes (Abbasi, Mohammadi, \& Chaharded, 2015), this industry is of special importance in the European Union (EU) and is seen as one of the strategic sectors of its economy. According to Cefic (2018), the EU is the second-largest chemical producer in the world after China. Accounting for 16 percent of the total value added, the chemical sector represents the leading sector in the EU manufacturing industry. It creates approximately 7.5 percent of the total manufacturing turnover of the EU, and its sales amount to approximately 565 billion EUR, which accounts for approximately 17 percent of global chemical sales (2018). Even though the EU is considered to be a selfsufficient economy in many ways and intra-EU trade represents almost twothirds of its overall international trade, there are still extra-EU areas and trading partners that cannot be substituted for. For instance, the USA and China, with trade shares of 17.1 percent and 15.4 percent, respectively, represented the major extra-EU trading partners of the EU in 2018. 
Base chemicals, including petrochemicals and their derivatives, along with basic inorganics, account for almost 60 percent of total chemical sales of the EU. The petrochemical industry represents the largest investor in the chemical sector of the EU, with investments totaling 6.5 billion EUR (one-third of the region's total investments in chemicals). Furthermore, it is the largest importer (36 percent in 2018) and the second-largest exporter (25 percent in 2018) in the chemical industry. Even though the EU trade balance of chemical commodities amounted to a surplus of 45 billion EUR in 2018, the petrochemical industry reported a trade deficit of 1.5 billion EUR after two years of reporting a trade surplus. Currently, the petrochemical sector is experiencing significant structural changes as it faces challenges posed by the increased competition from extra-EU countries and rising costs. In this paper, we consider the exchange rate to be one of the most important factors affecting the position of the EU petrochemical sector in the global market. Given that more than 90 percent of the overall EU petrochemical industry is based in eurozone countries, the paper is focused on the exchange rate sensitivity of this industry only as it relates to the euro exchange rate. Therefore, this study aims to evaluate the relationship between exchange rate fluctuations and stock market prices in the petrochemical industry of the eurozone.

The effect of the exchange rate on stock prices is currently the subject of wide research interest. Economic theory provides support for the existence of a causal relationship between stock prices and exchange rates. The well-known theoretical approach of the goods market channel (e.g., Dornbusch \& Fischer, 1980) considers exchange rates to be a determinant of the competitiveness of companies involved in international economic activities. The changes in exchange rates are thought to cause changes in the cash flow and stock price of a company. Depreciation of the domestic currency is thought to reduce the cost of exporting goods and is usually followed by an increase in foreign demand. Similarly, the appreciation of the domestic currency has an adverse effect on the cost of exporting and on foreign demand. Therefore, exchange rates have an impact on the value of payables and receivables denominated in foreign currencies. Furthermore, one cannot omit the 
effect of the market competition of foreign companies that causes exchange rate exposure even for domestic companies with purely domestic cash flows (Flota, 2014).

To explore this topic, the next section reviews the relevant literature published in the examined field. Section 3 introduces the empirical model and the data used in this study. Section 4 presents and discusses the empirical results. Finally, the last section makes concluding remarks.

\section{Review of the Relevant Literature}

The majority of the studies dealing with foreign exchange exposure follow the approach of Adler and Dumas (1984), who defined the extent of the exchange rate exposure of a company as the elasticity between the changes in the company's value and an exchange rate. The exposure coefficients are obtained by running linear regressions of stock returns on the changes in an exchange rate, and some researchers add control variables, such as the returns of the respective market index (Jorion, 1990). This definition of exchange rate exposure has been modified according to the methodological development of various studies and has been repeatedly used and applied to various geographic regions and periods.

The empirical evidence concerning this issue provides mixed results. The majority of the initial empirical studies confirmed that currency value has almost no impact on the stock prices of a firm (e.g., Jorion, 1990; Bartov \& Bodnar, 1994). However, some studies have clearly shown that exchange rate fluctuations do have an effect on these prices (e.g., Patro, Wald, \& Wu, 2002). More recent studies have provided a possible explanation for this ambiguous relationship by testing its effects using the different determinants of overall foreign exchanges. An overview of these studies can be found in Table 1 . 
Table 1: Main Determinants of the Relationship between Exchange Rate and Stock Prices

\begin{tabular}{|c|c|c|}
\hline Level & Determinant & Study \\
\hline \multirow{7}{*}{ Company } & Company size & $\begin{array}{l}\text { Jorion (1990), He and } \mathrm{Ng}(2002) \text {, Bodnar and Wong (2003), } \\
\text { Dominguez and Tesar (2006), Ampomah, Mazouz, and Yin } \\
(2013)\end{array}$ \\
\hline & $\begin{array}{l}\text { International } \\
\text { activities }\end{array}$ & $\begin{array}{l}\text { Allayannis and Ofek (2001), Dominguez and Tesar (2006), } \\
\text { Hagelin and Pramborg (2006), Brown and Minton (2010) }\end{array}$ \\
\hline & Competitiveness & Dominguez and Tesar (2006), Ampomah et al. (2013) \\
\hline & Hedging & Nance, Smith, and Smithson (1993), Ampomah et al. (2013) \\
\hline & Leverage & Ampomah et al. (2013) \\
\hline & Liquidity & Ampomah et al. (2013) \\
\hline & $\begin{array}{l}\text { Growth } \\
\text { opportunities }\end{array}$ & Nance et al. (1993), Ampomah et al. (2013) \\
\hline \multirow[b]{2}{*}{ Industry } & Price elasticity & Marston (2001), Ampomah et al. (2013) \\
\hline & $\begin{array}{l}\text { Substitution of } \\
\text { goods }\end{array}$ & Marston (2001), Ampomah et al. (2013) \\
\hline \multirow{4}{*}{$\begin{array}{l}\text { Macroeconomic } \\
\text { factors }\end{array}$} & International trade & Patro et al. (2002) \\
\hline & Credit rating & Patro et al. (2002) \\
\hline & Taxes & Patro et al. (2002) \\
\hline & Openness & $\begin{array}{l}\text { De Jong, Lingterink, and Macrae (2006), Hutson and } \\
\text { Stevenson (2010) }\end{array}$ \\
\hline
\end{tabular}

Source: Author's elaboration.

Ampomah et al. (2013) elaborated on the systematic categorization of the determinants of overall foreign exchange exposure. They divided the additional determinants into three basic levels - company, industry, and macroeconomic levels. The company-level characteristics cover those of international economic engagement, namely, hedging, size, leverage, liquidity, and growth opportunities (Ampomah et al., 2013). Given the assumption of domestic currency depreciation, the effect of this currency change on the company should be as follows. If the company has an unchanged volume of sales in a foreign currency, the company's revenues from abroad will increase in proportion to the respective domestic currency depreciation. At the same time, the company's competitiveness will increase as the international price of its exported products decreases. Using this theoretical framework, Jorion (1990) found that companies with a higher level of exports suffer from a higher level of positive exchange rate exposure. 
Furthermore, Bodnar and Wong (2003) confirmed that small firms have increased exposure to currency value changes compared to larger firms. On the one hand, this possibly results from the competition presented by larger companies. On the other hand, larger firms are more likely to hedge against currency risk than smaller firms. The use of hedging instruments can reduce exchange rate exposure (Nguyen \& Faff, 2003). In contrast, He and Ng (2002) showed that foreign exchange rate exposure increases as firm size increases. This possibly results from the higher level of engagement of larger companies in international economic activities (e.g., Allayannis \& Ofek, 2001; Hagelin \& Pramborg, 2006; Brown $\&$ Minton, 2010). In addition, the effect of growth opportunities should also be taken into account. Nance et al. (1993) revealed that companies with considerable growth opportunities tend to use hedging instruments more frequently, which results in a lower level of exchange rate exposure.

The industrial sector affiliation of a firm contains other important determinants of the relationship between exchange rate and stock prices. Industry competitiveness determines the price elasticity of demand and the degree of substitutability of the goods produced in the respective sector. We refer to Marston (2001) and Ampomah et al. (2013) for an excellent in-depth view of this issue.

From the macroeconomic perspective, Patro et al. (2002) found that the factors of international trade, credit ratings, and taxes are other significant determinants affecting exchange rate risk. The degree of the openness of the domestic country is another factor affecting the firm's degree of exposure (e.g., De Jong et al., 2006; Hutson \& Stevenson, 2010). Furthermore, a depreciation of the domestic currency can increase the competitiveness of even purely domestic companies. This situation occurs through the competition presented by the import-oriented industry. In this case, the depreciation of the domestic currency can cause a net positive impact on stock prices. However, as this depreciation can signal more fundamental problems, declines in the value of the domestic currency can also be accompanied by economic contraction and a decrease in stock prices. 
There are many studies concerning the effects of exchange rates on stock prices, some of which concern the petrochemical industry. For instance, these studies include those conducted by Li, Wang, and Zhao (2019), Sadorsky (2001), Choi (2010), and Šimáková and Rusková (2019). However, their results are mixed and cannot be generalized to the whole petrochemical sector. Furthermore, there is no summary study of EU petrochemicals. As mentioned above, the effect of exchange rate uncertainty on company performance depends on a variety of determinants. The overall effect and the direction of the foreign exchange rate exposure depend on the exact currency pairing and differ over time. The exposure coefficient can even suffer from measurement biases. Therefore, grouping firms by certain characteristics, notably by their industry sector, can lead to a less noisy estimate of their exchange rate exposure. Therefore, this paper focuses only on one industry while using control variables for the company and macroeconomic levels. Hence, this study substantially contributes to the scientific discussion in this field and fills the gap in the literature regarding the exchange rate exposure of companies operating in the petrochemical industry of EU countries.

\section{Methodology}

Adler and Dumas (1984) defined a company's extent of exchange rate exposure as the elasticity between the changes in the company's value and an exchange rate. Jorion (1990) added the control variable of the market index to this relationship and expressed it as a simple two-factor model. The stock return is used as the dependent variable, with two factors used as the independent variables, namely, the return on the market index and the respective exchange rate change. The model is represented by the following equation:

$R_{i t}=\alpha_{i}+\beta_{i} R M_{t}+\delta_{i} R F X_{t}+\varepsilon_{i t}$

where $\alpha_{i}$ represents the constant term, $R_{i t}$ is the stock return of company group $i$ during period $t, R M_{t}$ represents the return on the market index, $\beta_{i}$ is the company's market beta and $R F X_{t}$ is the real effective exchange rate (REER) of the domestic 
country. Therefore, the coefficient $\delta_{i}$ reflects the change in the stock returns, which is explained by the changes in the effective exchange rate following the recognition of the market return. The error term is represented by $\varepsilon_{i t}$.

According to the literature review in the second section of this paper, we study these effects only in one industry, and we add the variable of company size $S$, as it can be considered a proxy for a company's involvement in international economic activities and its use of hedging instruments, as well as a measure of the company's growth opportunities. Furthermore, following the most recent studies, we incorporate the control variables of Jorion's model. Following Cakan and Ejara (2013), we extend the model through the addition of variables representing the gold price $G$ and the oil price $O$ to examine their effects on the petrochemical industry:

$R_{i t}=\alpha_{i}+\beta_{i} R M_{t}+\delta_{i} R F X_{t}+\gamma_{i} R G_{t}+\lambda_{i} R O_{t}+\vartheta_{i} R S_{i}+\varepsilon_{i t}$

where $R G_{t}$ is the change in the gold price during period $t, R O_{t}$ represents the change in the oil price, and $R S_{i}$ is the company's size, in addition to the variables used in the first model. Coefficients $\gamma_{i}, \lambda_{i}$ and $\vartheta_{i}$ quantify the changes in the stock prices of the petrochemical industry caused by the change in the considered factor.

According to the literature review, the estimated exposure coefficient can suffer from measurement biases resulting from the methodology used. Recent empirical studies have tended to group companies by obvious characteristics, such as industry, company size, hedging, and the many other characteristics mentioned in the previous section. This grouping usually leads to a less noisy estimation of a particular foreign exchange rate exposure. Another challenge of estimating the exposure to exchange rate movements can be introduced by applying a crosssectional analysis that overlooks the time aspect of both the dependent and the explanatory factors. 
Taking into account the shortcomings of previous studies, this paper applies Jorion's model and panel data method (Šimáková, 2017). Therefore, the data are pooled across companies and time to improve estimation efficiency. This helps to avoid the risk of choosing an unrepresentative period and helps to monitor the unobservable specific effects of exchange rate changes on stock prices in the petrochemical industry. Furthermore, panel data analysis generates more accurate predictions of company outcomes by pooling the data. If a company's behaviors are similarly affected by certain variables, panel data provide the possibility of learning an individual variable's effects by observing the behavior of the others. Hence, panel data analysis leads to a more holistic explanation of a researched relationship by increasing the observations of an individual company through the addition of the data of other companies (e.g., Hsiao, 2006). Panel data contain information on intertemporal dynamics, and the individuality of the companies can control for the effects of missing or unobserved variables.

Before the ordinary least squares regression model is estimated using the panel data, the dataset effects must be identified as either random or fixed. If the heterogeneity in the model is unobservable but correlated with any variable included in the model, then fixed effects are present. In contrast, if the heterogeneity is unobservable and not correlated with any other variable, then random effects are present. To estimate the character of the dataset effects, this paper follows Tichý (2007) and applies the Breusch-Pagan test:

$L M=\frac{n T}{2(T-1)}\left[\frac{\sum_{i=1}^{n}\left(\sum_{t=1}^{T} e_{n}\right)^{2}}{\sum_{i=1}^{n} \sum_{t=1}^{T} e_{i t}^{2}}-1\right]^{2}$

where $T$ stands for the length of the time series, $n$ represents the number of elements in the cross-sectional dimension, and $e_{i t}$ stands for the residual term.

The economic relationship between the tested variables can be dynamic. Therefore, we also employ dynamic panel data analysis to illustrate the possible effects of 
lagged returns in stock prices and changes in exchange rates. In the context of dynamic panel data, we control for unobserved heterogeneity by applying the transformation by taking first differences. The ability of first differencing to remove unobserved heterogeneity lies in the estimators that have been developed for dynamic panel data models. Following Hsiao (2006), these models contain the stock price return and the lagged variables of the exchange rate change, allowing for the modeling of a partial adjustment mechanism.

\section{Results}

The sample period for the estimation covers the period from 2002/01 to 2018/06, and the sample is composed of publicly listed petrochemical companies from eurozone countries. The whole sample is created from a series of data taken from 38 companies consisting of 27 large companies and 11 small and medium-sized companies according to the number of their employees. Monthly data are used for the time series. A higher frequency is undesirable, as the indirect foreign exchange exposure derived from a competitive situation cannot appear in a shorter time. REER data for the variables FX were obtained from the Eurostat database. The REER index is calculated as the trade-weighted average of the domestic currency - the euro in our case - relative to the basket of major currencies from the international trade point of view. The trade weighting is based on the 42 major trading partners of each tested country. These data are adjusted for the effects of inflation to obtain accurate values. The consumer price index is employed as the deflator of REER.

The basic characteristics of the selected stock companies in the respective eurozone countries, along with the average REER of these countries, are presented in Table 2. The rest of the eurozone countries do not have any publicly traded companies in their petrochemical sectors. Slovakia, Slovenia, Cyprus, and Lithuania have not been eurozone countries since 2002 but are still included in the data sample. The data series for these countries is shortened according to their adoption of the 
euro. Data for market indices were obtained from the OECD iLibrary statistical database. The rest of the data were obtained from the Yahoo Finance database. A summary of the descriptive statistics related to the variables of the model is presented in Table 3.

Table 2: Characteristics of the Data Sample

\begin{tabular}{|c|c|c|c|c|}
\hline Country & Sample size & > 500 employees & $<500$ employees & Average REER \\
\hline Belgium & 2 & 2 & 0 & 1.0165 \\
\hline Finland & 1 & 0 & 1 & 1.0353 \\
\hline France & 7 & 4 & 3 & 1.0171 \\
\hline Ireland & 6 & 3 & 3 & 1.0069 \\
\hline Italy & 5 & 4 & 1 & 1.0061 \\
\hline Cyprus & 1 & 1 & 0 & 1.0095 \\
\hline Lithuania & 1 & 0 & 1 & 1.0871 \\
\hline Germany & 1 & 1 & 0 & 1.0626 \\
\hline The Netherlands & 4 & 3 & 1 & 0.9986 \\
\hline Portugal & 1 & 1 & 0 & 1.0075 \\
\hline Austria & 1 & 1 & 0 & 1.0242 \\
\hline Greece & 3 & 3 & 0 & 1.0043 \\
\hline Slovakia & 1 & 1 & 0 & 1.0689 \\
\hline Slovenia & 1 & 1 & 0 & 0.9793 \\
\hline Spain & 3 & 2 & 1 & 1.0077 \\
\hline Whole sample & 38 & 27 & 11 & 1.0254 \\
\hline
\end{tabular}

Source: Author's calculations.

Table 3: Descriptive Statistics of the Research Variables

\begin{tabular}{l|c|c|c|c}
\hline Variable & Average & Standard deviation & Skewness & Kurtosis \\
\hline Company return & 0.752 & 0.224 & 0.194 & 2.731 \\
\hdashline Market return & 0.867 & 0.288 & 0.187 & 2.514 \\
\hline Exchange rate & 1.0254 & 0.124 & 0.226 & 1.267 \\
Gold price & $1,288.630$ & 214.682 & -0.154 & 2.681 \\
Crude oil price & 82.067 & 15.804 & -0.925 & 3.127 \\
Beta risk & 0.249 & 0.085 & -0.015 & 2.914 \\
Company size & 246.32 & 3.672 & 0.143 & 1.658 \\
Sample size & & & & \\
\hline Observation & & & & 38 \\
\hline
\end{tabular}

Source: Author's calculations. 
Because the period of each company's listing on the market and its respective country's adoption of the euro can differ, the panels used for the regression testing are unbalanced. The Breusch-Pagan test revealed fixed effects in this case.

In the empirical testing of our model, we follow Hatemi-J and Roca (2006) to test the effect of the financial crisis on the tested relationship first. The panel regressions are estimated for three periods: the whole sample (2002/01-2018/06), the precrisis period (2002/01-2008/09), and the postcrisis period (2008/10 2018/06). These divisions allow for the testing of the persistence of exchange rate exposure in the petrochemical sector over time. The results of the panel regression according to the time period divisions are presented in Table 4.

Table 4: Estimated Coefficients of Panel Regression Analysis According to the Time Period

\begin{tabular}{|c|c|c|c|}
\hline Variable & Whole sample & Precrisis & Postcrisis \\
\hline Market return & $\begin{array}{c}0.341^{* * *} \\
(0.081)\end{array}$ & $\begin{array}{c}0.471^{* * *} \\
(0.185)\end{array}$ & $\begin{array}{c}0.261^{* * *} \\
(0.116)\end{array}$ \\
\hline Exchange rate change & $\begin{array}{c}-0.001^{* * *} \\
(0.0001)\end{array}$ & $\begin{array}{l}-0.001^{* *} \\
(0.0005)\end{array}$ & $\begin{array}{c}-0.149^{* * *} \\
(0.053)\end{array}$ \\
\hline Gold price change & $\begin{array}{l}-0.004 \\
(0.001)\end{array}$ & $\begin{array}{c}0.017 \\
(0.008)\end{array}$ & $\begin{array}{c}-0.008^{*} \\
(0.003)\end{array}$ \\
\hline Crude oil price change & $\begin{array}{l}0.015^{* *} \\
(0.007)\end{array}$ & $\begin{array}{c}0.024^{* * *} \\
(0.009)\end{array}$ & $\begin{array}{l}0.011^{* *} \\
(0.004)\end{array}$ \\
\hline Beta risk & $\begin{array}{c}0.245^{* * *} \\
(0.137)\end{array}$ & $\begin{array}{c}0.089^{* * *} \\
(0.041)\end{array}$ & $\begin{array}{c}0.257 \\
(0.094)\end{array}$ \\
\hline Change in company size & $\begin{array}{l}0.002^{* * *} \\
(0.0009)\end{array}$ & $\begin{array}{c}0.052^{* *} \\
(0.020)\end{array}$ & $\begin{array}{c}0.043^{* * *} \\
(0.016)\end{array}$ \\
\hline Adjusted coefficient of determination & 38.67 & 42.91 & 45.25 \\
\hline
\end{tabular}

Note: ${ }^{* * *},{ }^{* *},{ }^{*}$ denote significance at the $1 \%, 5 \%$, and $10 \%$ levels, respectively; standard deviations in parentheses. Source: Author's calculations.

In the case of the whole period, it can be confirmed that the model is significant at the 5 percent level. The coefficient of determination of the model also indicates that 38.67 percent of the changes in stock return are explained by this model. The petrochemical sector of the eurozone is shown to be significantly exposed to exchange rate risk at the 1 percent level during the whole sample period. The negative exposure coefficient suggests that the depreciation of the domestic 
currency is followed by an increase in the firm's stock returns. The results obtained from this paper are similar to those that were obtained by Abbasi et al. (2015). However, the coefficient of this variable is almost zero, which could be caused by the use of natural hedging or other sophisticated hedging instruments. Furthermore, Table 4 shows that the coefficient with the highest statistical significance is the coefficient of the market return. A 1 percent change in the market return causes more than a 3.4 percent change in the stock prices of petrochemical companies. Consistent with our assumptions, the results reveal that the crude oil price (at the 5 percent level) and the company size also affect the stock prices of the tested companies.

A slightly different result can be seen when we only use the data from the precrisis period (2002/01-2008/09). This estimation confirms that the stock returns are significantly sensitive to changes in the exchange rate, but only at the 5 percent level. The negative exposure coefficient is still very low and suggests that a depreciation in the domestic currency is followed by an increase in the company's stock returns. Furthermore, Table 4 shows that the highest statistically significant coefficient is again the coefficient of the market return. In comparison to the whole period, the coefficient is even higher in this period. In accordance with our assumptions, the results reveal that the crude oil price (at the 1 percent level) and the company size (at the 1 percent level) affect the stock prices of the tested companies as well. The change in the gold price remains free of any statistically significant effect on petrochemical stock prices. However, this model explains 42.91 percent of the changes in the stock return.

The results for the postcrisis period (2008/10-2018/06) also confirm that the market impact is the most important factor affecting changes in the stock prices of the petrochemical industry. Comparing all the panel regression models, we can see that the stock returns are significantly sensitive to the exchange rate change with a higher coefficient in the postcrisis period. The negative exposure coefficient suggests that a 1 percent decrease in the REER of the euro is followed by a 1.49 percent increase in the firm's stock returns, which corresponds, for example, with 
the studies by Sadorsky (2001) and Choi (2010). The discovered effects of changes in the crude oil price (at the 5 percent level), changes in the gold price (at the 10 percent level), and the company size (at the 1 percent level) are fully in line with economic theory and previous empirical findings (e.g., Cakan \& Ejara, 2013; Bodnar \& Wong, 2003; Dominguez \& Tesar, 2006; Ampomah et al., 2013).

Table 5: Estimated Coefficients of Panel Regression Analysis According to Company Size

\begin{tabular}{|c|c|c|}
\hline Variable & $>500$ employees & $<500$ employees \\
\hline Market return & $\begin{array}{c}0.385^{* * *} \\
(0.069)\end{array}$ & $\begin{array}{c}0.247^{* *} \\
(0.081)\end{array}$ \\
\hline Exchange rate change & $\begin{array}{l}-0.004^{* *} \\
(0.0006)\end{array}$ & $\begin{array}{l}-0.213^{*} \\
(0.092)\end{array}$ \\
\hline Gold price change & $\begin{array}{c}0.015 \\
(0.002)\end{array}$ & $\begin{array}{c}0.009 \\
(0.001)\end{array}$ \\
\hline Crude oil price change & $\begin{array}{l}0.101^{* *} \\
(0.037)\end{array}$ & $\begin{array}{l}0.014^{* *} \\
(0.008)\end{array}$ \\
\hline Beta risk & $\begin{array}{l}0.148^{* *} \\
(0.067)\end{array}$ & $\begin{array}{c}0.206^{* *} \\
(0.050)\end{array}$ \\
\hline Change in company size & $\begin{array}{l}0.027^{*} \\
(0.007)\end{array}$ & $\begin{array}{c}0.041^{* *} \\
(0.057)\end{array}$ \\
\hline Adjusted coefficient of determination & 49.82 & 34.17 \\
\hline
\end{tabular}

Note: ${ }^{* * *},{ }^{* *},{ }^{*}$ denote significance at the $1 \%, 5 \%$, and $10 \%$ levels, respectively; standard deviations in parentheses. Source: Author's calculations.

The results of the panel regressions according to company size are presented in Table 5. Because the tested companies in this analysis are mostly large and, in a few cases, medium-sized, only two panels are estimated. One panel regression is performed for companies with fewer than 500 employees, and another is performed for companies with a higher number of employees. The economic literature suggests that smaller firms are more exposed to currency value development than larger companies. The presented models are in accordance with findings by Allayannis and Ofek (2001), Hagelin and Pramborg (2006), and Brown and Minton (2010). Smaller companies tend to hedge less than larger companies; therefore, we observe currency exposure in more cases involving smaller firms. 
Furthermore, we run a dynamic panel data analysis. Employing the panel data, we can rely on the interindividual differences in the data to reduce the collinearity between current and lag variables and estimate unrestricted time-adjustment patterns. This approach of differencing the variables is suitable for our case, as we have a relatively low number of companies and a high number of observations over time. In this model, the differences on the 1st level (2nd difference of the state variable) eliminate the correlation in the panel model. The results of this estimation can be seen in Table 6 .

Table 6: Estimated Coefficients of Dynamic Panel Regression

\begin{tabular}{l|c}
\hline Variable & Coefficients \\
\hline Market return lag 1 & $0.139^{* *}$ \\
& $(0.077)$ \\
\hline Exchange rate change lag 1 & -0.003 \\
Gold price change & $(0.001)$ \\
\hline Crude oil price change & 0.088 \\
& $(0.023)$ \\
Beta risk & $0.016^{* *}$ \\
\hline Change in company size & $(0.008)$ \\
\hline Adjusted coefficient of determination & $0.651^{* *}$ \\
\hline m1 & $(0.209)$ \\
\hline m2 & 0.021 \\
Sargan test & $(0.004)$ \\
\hline
\end{tabular}

Note: ${ }^{* * *},{ }^{* *},{ }^{*}$ denote significance at the $1 \%, 5 \%$, and $10 \%$ levels, respectively; standard deviations in parentheses. Source: Author's calculations.

For the dynamic panel data model, the coefficient of determination indicates the lowest adjusted coefficient of determination of any of our models. Only 29.13 percent of changes in stock return are explained by this model. Moreover, the stock returns remain free of effects caused by the lagged value of the exchange rate. A possible explanation for this phenomenon arises from the prediction of the changes in exchange rate. Even smaller companies can predict the development 
of the exchange rate, at least by using the forward exchange rate for the respective period, and can incorporate this information into the decision-making process involving international cash flows.

\section{Conclusion}

The relationship between the risk in the market and the return of a respective asset is one of the essential concerns of individuals who trade stocks, manage portfolios, or are involved in the capital budgeting of a company. This issue is of primary relevance in sectors such as the petrochemical industry. Considering the importance of this industry as one of the strategic sectors in the eurozone economy, this study aimed to evaluate the relationship between exchange rate fluctuations and stock market prices in the petrochemical industry of this region. The last decade has been particularly turbulent for the petrochemical industry. Various political, economic, and financial crises have impacted the demand and supply of global petroleum and subsequently have affected the whole sector and the stock prices of petroleum companies as well. This paper sheds new light on the tested relationship by applying an extended version of Jorion's model and a panel regression model to the sample period between 2002 and 2018.

This paper showed that the petrochemical sector of the eurozone was exposed to exchange rate risk that was significant at the 1 percent level during the whole sample period and was still exposed to exchange rate risk even when we split the tested period into precrisis and postcrisis datasets. However, we observed that foreign exchange rate exposure tended to be higher after the beginning of the financial crisis in 2008. Moreover, in the past, the exchange rate was considered the key factor of a company's profitability, especially in trade-intensive sectors, such as petrochemical sectors. The negative exposure coefficient suggests that the depreciation of the euro is followed by an increase in petrochemical companies' stock returns in the eurozone. Furthermore, the paper confirmed assumptions 
about higher exposure to exchange rate changes in the cases of small and mediumsized companies.

Given the existence of a significant relationship between the exchange rate fluctuations and the stock returns of the companies operating in the petrochemical sector, investors are advised to consider the historical and predicted changes and trends in the exchange rate as part of the basis of their decision process. Furthermore, companies should be more focused on managing their foreign exchange risk during times when exchange rates are more volatile and the major foreign income currencies are depreciating against the euro.

The efforts of petrochemical companies are also supported by the attempt of the EU to increase the competitiveness of this industry, mainly through the implementation of policies that facilitate structural change, help to attract investment to the EU, help to support investment in research and innovation, and many other similar policies. However, as a result of the engagement of these companies in extra-EU trade with an overall deficit, and considering the results of this paper, the competitiveness of these companies can be increased even through the effect of the monetary policies of the eurozone on the development of the euro exchange rate.

This paper provides a beneficial background for further research on the EU petrochemical industry. Further research could be based on testing the microdata of company cash flows. Additionally, the research could be extended by addressing the possible asymmetric effects of the changes in the exchange rate on the performance of the company, as the intensity of the effects of the appreciation of a currency may not be the same as that under the effects of depreciation.

\section{Acknowledgements}

Publication of this paper was supported by the Student Grant System of Silesian University [project SGS/23/2016]. The support is gratefully acknowledged. 


\section{Literature}

Abbasi, G. R., Mohammadi, H. M., \& Chaharded, O. M. (2015). The study of the effects of exchange rate fluctuations on petrochemical industry return in Tehran Stock Exchange. European Online Journal of Natural and Social Sciences, 4(1), 1170-1179. Retrieved from: http://european-science.com/eojnss_proc/ article/view/4325

Adler, M., \& Dumas, B. (1984). Exposure to currency risk: Definition and measurement. Financial Management, 13, 41-50.

Allayannis, G., \& Ofek, E. (2001). Exchange rate exposure, hedging, and the use of foreign currency derivatives. Journal of International Money and Finance, 20(2), 273-296. doi: https://doi.org/10.1016/S0261-5606(00)00050-4

Ampomah, S. A., Mazouz, K., \& Yin, S. (2013). The foreign exchange exposure of UK non-financial firms: A comparison of market based methodologies. International Review of Financial Analysis, 19, 251-260. doi: https://doi. org/10.1016/j.irfa.2012.05.006

Bartov, E., \& Bodnar, G. M. (1994). Firm valuation, earnings expectations and the exchange-rate exposure effect. Journal of Finance, 49(5), 1755-1785. doi: https://doi.org/10.1111/j.1540-6261.1994.tb04780.x

Bodnar, G. M., \& Wong, F. M. H. (2003). Estimating exchange rate exposure: Issues in model structure. Financial Management, 32(1), 35-67.

Cakan, E., \& Ejara, D. (2013). On the relationship between exchange rates and stock prices: Evidence from emerging markets. International Research Journal of Finance and Economics, 111(7), 115-124.

Cefic. (2018). Facts \& figures of the European chemical industry. Retrieved from: https://www.apquimica.pt/uploads/fotos_artigos/files/cefic-facts-and-figures2018-industrial.pdf

Choi, S. (2010). Estimating exchange rate exposure of trade-intensive firms: Application to Korean oil-refiners and petrochemicals. Global Economic Review, 39(3), 327-348. doi: https://doi.org/10.1080/1226508X.2010.513144 
De Jong, A., Lingterink, J., \& Macrae, V. (2006). A firm-specific analysis of the exchange rate exposure of Dutch firms. Journal of International Financial Management and Accounting, 17(1), 1-28. doi: https://doi.org/10.1111/j.1467646X.2006.00119.x

Dominguez, K. M. E., \& Tesar, L. L. (2006). Exchange rate exposure. Journal of International Economics, 68(1), 188-218. doi: https://doi.org/10.1016/j. jinteco.2005.01.002

Dornbusch, R., \& Fischer, S. (1980). Exchange rates and the current account. The American Economic Review, 70(5), 960-971.

Flota, C. (2014). The impact of exchange rate movements on firm value in emerging markets: The case of Mexico. American Journal of Economics, 4(2A), $51-72$.

Hagelin, N., \& Pramborg, B. (2006). Empirical evidence concerning incentives to hedge transaction and translation exposure. Journal of Multinational Financial Management, 16(2), 142-159.doi:https://doi.org/10.1016/j.mulfin.2005.05.003

Hatemi-J, A., \& Roca, E. (2006). Exchange rates and stock prices interaction during good and bad times: Evidence from the ASEAN4 countries. Applied Financial Economics, 15(8), 539-546. doi: https://doi.org/10.1080/09603100500056635

He, J., \& Ng, L. K. (2002). The foreign exchange exposure of Japanese multinational corporations. Journal of Finance, 53(2), 733-753. doi: https://doi. org/10.1111/0022-1082.295575

Hsiao, C. (2006). Panel data analysis: Advantages and challenges. IEPR Working Paper No. 06.49. doi: https://doi.org/10.2139/ssrn.902657

Hutson, E., \& Stevenson, S. (2010). Openness, hedging incentives and foreign exchange exposure: A firm-level multi-country study. Journal of International Business Studies, 41(1), 105-122. doi: https://doi.org/10.1057/jibs.2009.32

Jorion, P. (1990). The exchange rate exposure of U.S. multinationals. Journal of Business, 63(3), 331-345. doi: https://doi.org/10.1086/296510 
Li, G., Wang, Z., \& Zhao, Y. (2019). Exchange rate exposure: Evidence from China. Review of International Economics, 27(4), 1148-1171. doi: https://doi. org/10.1111/roie.12411

Marston, R. C. (2001). The effects of industry structure on economic exposure. Journal of International Money and Finance, 20(2), 149-164. doi: https://doi. org/10.1016/S0261-5606(00)00052-8

Nance, D. R., Smith, C., \& Smithson, C. (1993). On the determinants of corporate hedging. Journal of Finance, 48(1), 267-284. doi: https://doi. org/10.1111/j.1540-6261.1993.tb04709.x

Nguyen, H., \& Faff, R. (2003). Can the use of foreign currency derivatives explain variations in foreign exchange exposure? Evidence from Australian companies. Journal of Multinational Financial Management, 13(3), 193-215. doi: https://doi. org/10.1016/S1042-444X(02)00051-8

Patro, D. K., Wald, J. K., \& Wu, Y. (2002). Explaining exchange rate risk in world stock markets: A panel approach. Journal of Banking and Finance, 26, 1951-1972. Retrieved from: https://papers.ssrn.com/sol3/papers.cfm?abstract_id=327920

Sadorsky, P. (2001). Risk factors in stock returns of Canadian oil and gas companies. Energy Economics, 23, 17-28.

Šimáková, J. (2017). The impact of exchange rate movements on firm value in Visegrad countries. Acta Universitatis Agriculturae et Silviculturae Mendelianae Brunensis, 65(6), 2105-2111. doi: https://doi.org/10.11118/ actaun201765062105

Šimáková, J., \& Rusková, N. (2019). The role of exchange rates in the stock price development of chemical companies in the Visegrad Four countries. Comparative Economic Research, 22(3), 117-129. doi: https://doi.org/10.2478/cer-2019-0026

Tichý, F. (2007). Impact of accession to EMU on international trade - Case of the Czech Republic. Prague Economic Papers, 16(4), 336-346. doi: https://doi. org/10.18267/j.pep.312 